\title{
Final Report on the Research of 2021 American Economy
}

\author{
Anqi Li \\ Cushing Academy, Ashburnham, Massachusetts, United States \\ angelali0501@163.com
}

\begin{abstract}
In the past decade, America's inflation rate has always been mysteriously low, varying around 1\% 3\% ("United States," 2021). However, to everyone's surprise, the inflation rate has reached 5\% ("United States," 2021) in June 2021, far higher than the Federal Reserve's 3.4\% (Smart, 2021) prediction made in this year.
\end{abstract}

Keywords: Inflation Rate; Federal Reserve; Predict.

\section{Why is this Inflation Rate so High?}

To begin with, one of the biggest reasons for the current soaring inflation is the rapid rebound of demands recovering from the pandemic. Now that Americans are generally vaccinated, their need for tourism has recovered. The demand for airfares, hotels, and second-hand cars skyrocketed (Long et al., 2021). However, due to the little demand during the pandemic, the supply of these markets is still on a small scale, causing the price to soar, with respective increases of 9.5\% (Whitmore, 2021), 1.2\% (from $\$ 185$ pre-pandemic to $\$ 220$ in July) (Whitmore, 2021), 30\% (Long et al., 2021) on prices in June 2021. This rebound in tourism also causes gasoline prices to go up at a shocking rate of 56\% over the last May (Long et al., 2021).

The rapid rebound also happens beyond the market of tourism, such as home appliance markets, with an increase as of June 2021 of 27\% (Long et al., 2021) on washers and dryers, 9\% (Long et al., 2021) on furniture, and $10 \%$ (Long et al., 2021) on bikes.

Inflation might continue to increase in the future because of Biden's American Jobs Plan, which will make an expenditure of 1.9 trillion dollars on public transits, such as renovating highways, buses, railways, and metros; constructing infrastructure system such as building broadbands, purifying drinking water, and renewing public school facilities. The White House estimates that the plan will open millions of job opportunities to Americans, lowering the currently high unemployment rate to below 3\%, and eventually causing America's debt to decrease by $0.9 \%$ compared to that of May 2021. ("FACT SHEET," 2021)

As a Keynesian, Biden expects workers to occupy these job positions spontaneously after they are opened, but that's not how reality runs. In June, there are still 8 million job positions empty in America. Some workers are reluctant to go back to work. This is partly caused by high unemployment benefits. In May 2021, 15.8 million people were covered by the unemployment benefits (Rugaber, 2021). Only a small number of workers are willing to work 8 hours a day when they can get 300 dollars a week ("The Curious," 2021) from sitting at home. Significant numbers of empty job positions in industries such as construction will cause companies to provide higher and higher wages to attract workers and compete with rivals. Higher salaries will push higher commodity prices, and higher commodity prices will again drive-up salaries.

The way to solve this problem is not merely canceling the job protection, as 20 states claims that they will cancel job aids in June (Rugaber, 2021). Because the Australian government has suffered an even higher unemployment rate after it withdrew its job protection. A better solution would be to change the form of incentive instead of withdrawing job aids immediately, as it promotes people to find jobs while keeping them in a stable mood. An example would be Arizona's decision of giving anyone who works a full-time job 2000 dollars ("The Curious," 2021).

In addition to the analysis of Biden's plan, the White House's expectation that companies to react quickly to their Jobs plan is over estimated, for they are planning on publishing another 4 trillion 
dollars expenditure plan, which funds its expenditure primarily by taxation from companies. This plan adds another high cost to the already high pressure of providing salaries.

Another reason for the current inflation rate is America's massive decrease in import rate in 2020. Because of the pandemic and political tensions with China, America's import rate in 2020 had a 6.2 billion (2.4\%) decrease from 2019 ("United States," 2021), causing less currency to flow to other countries. When the aggregated supply stays the same, and the amount of currency increases, the commodity prices and the inflation rate soars. Although America has increased its import rate by $39.2 \%$ in 2021 ("United States," 2021), that does not mean the situation will get any better. Since increasing imports means there's more competition from other countries and fewer job opportunities for Americans. And now, customers would want to choose cheaper and perhaps better qualified foreign goods. This contradicts Biden's plan of reducing unemployment and the White House's promise of providing more job opportunities for American workers. It's also against the announcement the White House made of reducing international competitions against local companies. If they insist on increasing imports, they might lose their voters' favor.

\section{What are the Effects Inflation Causes?}

First, inflation's most prominent effect is that it'll cause wages and rents to rise (Long et al., 2021). As the commodity prices increase, workers and landlords are asking for higher salaries and rents. Companies, therefore, will allocate these new costs to customers, which means they'll raise their products' prices, causing the commodity prices to increase again and eventually forming a vicious cycle.

Inflation on tourism and house appliances won't cause a huge effect on the economy, for the supply will eventually catch up with the demands, and inflation will fade. However, rent prices often remain the same for years, which causes inflation to last (Long et al., 2021).

\section{Who Suffers and Who Benefits from the High Inflation?}

The ones who suffer the most are the statutory poor in America. They spend most of their income on daily commodities, yet the rise of their wages is out of proportion with the increase of commodity prices, which means they could no longer afford some of their necessities (Long et al., 2021).

Enterprises that signed long-term contracts with inflexible price changes of their products also suffer from this inflation. Companies might have signed these contracts with other partner companies, with the governments because they are monopolies, or with the head office because they are franchise stores. With wages constantly increasing as a new cost, they cannot add this cost onto customers, for their inflexible contracts do not allow to raise prices. This situation reduces their profits, and some unfortunate ones can even go bankrupt.

The ones who benefit the most are debtors and American government, because the rise of commodity prices means the purchasing power of American dollars is decreasing. When dollars are less valuable, yet the debtors and the government's debt do not increase, it suggests that they currently own less debt than they should have owned (Long et al., 2021).

\section{What is the Federal Reserve going to do About it?}

The Federal Reserve just released its plan in June, claiming that although the inflation will fade eventually, it is currently intensifying much more quickly than they have expected. Therefore, they would increase the interest rate sooner than planned, from 2024 to 2023 ("New Horizons," 2021). Moreover, because the inflation rate is rising too fast, there is also a trend in the Federal Reserve's officials to raise interest rate in 2022, even before 2023 (White, 2021).

While the Federal Reserve is trying to get the inflation rate back to $2 \%$, the investors perceive this as terrible news, for it is going to become more challenging for them to get loans in the future due to 
the higher interest rates. They will probably have to alter or abandon their future investment plans due to the Federal Reserve's decision ("New Horizons," 2021).

The bond market has already reacted to this news. Now that people expect inflation to continue in the short term, the yields for two years, three years, and five years bonds increase rapidly to reattract customers. Then, because of the Federal Reserve's deflation plan, the yields for long-term bonds: ten years and thirty years have respectively dropped to $1.5 \%$ and less than that ("New Horizons," 2021). These changes in yields indicate that marketers expect the inflation rate to rise in the short term and reduce in the long term.

Still, although this increase in interest rates has created many uncertainties in the U.S economy, it helps investors to mentally prepare for the upcoming rise of interest rates. It provides them time to change or cancel their investment plan, so they will not panic when it is finally their turn to pay more interest.

However, Powell, the chair of the Federal Reserve, is currently worried that if they raise the interest rate too soon, it will again cause the unemployment rate to increase. There are already millions of American citizens out of their jobs. The Federal Reserve cannot afford more unemployment (White, 2021).

\section{Why Biden's American Jobs Plan would not Work?}

Although the workers' low incentives are reversible, it does not mean this is all it takes to make this enormous plan work the way Biden has envisioned, because the labor force and the labor market cannot be regarded as the biggest reasons for the high unemployment rate.

An important reason for the high unemployment rate is the fact that most American workers are not qualified enough to handle much of the technical work emerging industries require (although in the construction industries, they are also lacking more than one million unskilled workers (Rugaber, 2021)). In addition, the accelerating globalization only made things worse. In the past few decades, more and more foreign elites from India, China, and Europe came to work in America. Moreover, not just scholars, unskilled workers are also searching for jobs in America with lower requirements. As America slowly starts issuing its visas, they will again, come in large numbers. With these new labor supplies, local American workers are slowly losing their competitiveness. The biggest reason America's vacancies are so high is that it is not until recently they have just started issuing the visa, allowing few foreign workers to come into America ("The Curious," 2021). Still, the vacancy rate's reduction is not related to the unemployment rate among American workers, because these job positions will not be filled by domestic workers. Therefore, these American workers will remain jobless.

The proper solution for the White House might not be creating more job positions for workers. Instead, they might want to focus on restructuring the entire supply chain and adapting American workers' abilities more to reduce the unemployment rate. For reformations on the demand side are only useful temporarily, if American government want to make long-term influences, they might want to change the supply side.

\section{What American Government can Learn from China's Supply-side Structural Reform?}

China, however, had already proposed the plan of Supply-side Structural Reform back in November 2015 and implemented it throughout these six years.

Yet, unlike America, China's problem was capacity. After its once rapid GDP growth slowed down, the problems beneath that fast pace of development appeared. China was facing overcapacity in lowend products and insufficient capacity in high-end products. Still, what cannot be ignored is that it was also facing the consequences of the 2008 Sub-prime Mortgages crisis, which led to economic recession (Jiang \& Gu, 2015). 
Before 2015, China had put all its efforts into stimulating mass productions without regulating the products' qualities and all possible externalities. This reckless stimulation caused China's products to be low qualified compared to the foreign products and caused massive pollution and environmental problems throughout China. Therefore, before 2015, Chinese customers bought more foreign products and the Chinese economy was lagging. Moreover, Chinese government considered that there were too many companies producing low-end products such as daily commodities like food and clothes, and too few companies were producing high-end products like electronic chips, which caused China's economy and development to rely on other developed countries, like America (Bao, 2021).

To solve this problem, China quickly redesigned its economic strategies. Before 2015, Chinese government was just like American government, mostly conducting policies on the demand side, such as lowering interest rates and increasing government expenditure. Yet, the demand side policies only have their effects in the short run. If the government does not restructure the supply side, which is the core issue, both unemployment and overcapacity will reoccur.

To restructure the supply side, the government first needs to understand the reason of overcapacity. In China's case, it's because of the low quality of local products. To increase the products' quality, the government promoted competition. It gave out policies that have eliminated corruption within the government, cracked down monopolies and oligopolies, improved the trading system to reduce transaction costs, merged and reorganized many state-owned enterprises, and reduced tax burdens. In the long run, these policies promoted the emergence of many tertiary industry enterprises. By increasing their percentage in the economy, and reducing the rate of traditional secondary industries, they successfully solved the overcapacity issue, the reliance on other countries, and the slow recovery from the Sub-prime mortgage crisis (Jiang \& Gu, 2015).

What I believe is that, although different in appearance, America's unemployment issue is essentially like China's overcapacity problem. Opening job positions might only reduce the unemployment rate temperately, considering these job positions will disappear once the construction on infrastructures is completed. A better solution might be to increase the quality of American workers so that they meet the requirements of more challenging jobs. Or, more feasible, to promote traditional secondary industries that suit these workers' abilities. The emergence of large numbers of secondary industries will open long-term job positions for these American workers so they will not remain jobless when the next decade arrives.

In conclusion, the current high inflation rate is mainly caused by the rapid rebound of demands and inefficient government decisions. Still, it will eventually decrease to its average rate (between $1 \%$ to $3 \%$ ) as the supplies of tourism and other markets catch up with their demands. By quickly reopening its import business and increasing the interest rate for deflation will also boost the process. However, the biggest concern for the government might not be inflation but rather the intense unemployment situation in America, with millions of workers waiting for jobs. To fix this, Biden and his team might want to consider reforming the structure of the supply side instead of the demand side, for restructuring the demand side only solves the unemployment problem temporarily. Only reforming the supply side and conducting supply side policies can improve the situation in the long run.

\section{References}

[1] Budryk, Z. (2021, July 6). Gas prices projected to increase up to 20 cents over summer. The Hill. https://thehill.com/policy/energy-environment/561711-gas-prices-projected-to-increase-up-to-20-centsover-summer?rl=1.

[2] Jiang, C., Gu, T. (September 15th, 2018). Supply-side reform background, policies, and impact. Haitong Securities. https://wenku.baidu.com/view/7e384ab2dc36a32d7375a417866fb84ae55cc34a.html.

[3] Leaders (2021, June 26). Investors can no longer take low interest rates for granted. The Economist. https://www.economist.com/leaders/2021/06/26/investors-can-no-longer-take-low-interest-rates-forgranted. 
[4] Leaders (2021, May 22). What to do about a labour crunch. The Economist. https:// www. economist. com/leaders/2021/05/22/what-to-do-about-a-labour-crunch.

[5] Long, H., Dam, A. V., Fowers, A. (2021, June 17). FAQ: Why inflation is rising and whether you should worry. The Washington Post. https://www.washingtonpost.com/business/2021/06/10/inflation-what-toknow/.

[6] Rugaber, C. (2021, May). More jobless getting aid than in past even as cutoffs loom. AP NEWS. https:// apnews.com/article/pandemics-jobless-claims-coronavirus-pandemic-health-business-a7ea3e65542c137 $865 b d 449626 b 31461$.

[7] Smart, T. (2021, June 16). Gas prices projected to increase up to 20 cents over summer. U.S. News. https:// www.usnews.com/news/national-news/articles/2021-06-16/fed-raises-inflation-and-economic-forecasthints-at-first-rate-hike-in-2023.

[8] Trading Economics. (2021. n.d). United States Imports1950-2021 Data: 2022-2023 Forecast: Calendar: Historical. Trading Economics. https://tradingeconomics.com/united-states/imports.

[9] Trading Economics. (2021. n.d). United States Inflation Rate1914-2021 Data: 2022-2023 Forecast: Calendar. Trading Economics. https://tradingeconomics.com/united-states/inflation-cpi.

[10] The White House (2021, May 4). FACT SHEET: The American Jobs Plan. The White House. https: // www.whitehouse.gov/briefing-room/statements-releases/2021/03/31/fact-sheet-the-american-jobs-plan/.

[11] White, B. (2021, July 01). 'Jay's job to lose': Powell's reappointment by Biden as Fed chief hangs on inflation. POLITICO. https://www.politico.com/news/2021/07/01/powell-biden-fed-interest-rates-49742 5.

[12] Whitmore, G. (2021, May 27). Increase In Travel Is Causing Travel Prices to Rise. Forbes. https:// www. forbes.com/sites/geoffwhitmore/2021/05/27/increase-in-travel-is-causing-travel-prices-to-rise/?sh=30f0 b13274c1. 